\title{
STATE TRADING AND ECONOMIC WARFARE
}

\author{
Robert LoRing ALLEN*
}

\section{INTRODUCTION}

International trade theory and policy have customarily treated state trading and economic warfare as temporary aberrations from the norm. The "normal" world is one in which each of the many nations strives to maximize output, in part by specializing in the production of items in which it has a comparative advantage, where private interests seeking profits buy in the cheapest markets and sell in the dearest markets. This search for the gains from trade is conducted within the framework of convertible currencies, with automatic mechanisms determining the principal economic variables-exchange rates, prices, income-and carrying the burden of adjustments in the relatively free flow of goods and services across national borders.

This model, of course, exists only in the mind. Historically, however, there have been approximations to it, particularly in the nineteenth century. Some permanent departures from the model have received widespread recognition. Interference with trade in order to foster high-cost but potentially competitive industries has long been acceptable. Discrimination through various forms of exchange controls, including multiple rates, rationing, quotas, and bilateral balancing of trade have become ordinary policies with, in some cases, an economic justification.

State trading, however, has never been fully accepted as one of the standard methods for conducting international trade. Despite its age-state trading came in about the same time taxes did, when governments began functioning-and its incidence-every government trades to some extent-state trading has always been treated as the exception, as a nonconforming device not really within the framework of the doctrines of international economic analysis. Economic warfare, in one or another of its many manifestations, has also been regarded as an abnormality, associated with military warfare or the preparations for it and with the special role and actions of the occasional predatory nation which seeks to better its position at the expense of others.

State trading calls to mind the trading activities of the Soviet Union since the Revolution, and economic warfare the actions of Germany in Southeast Europe in the years immediately preceding World War II. While these are apt illustrations, they by no means illuminate the pervasive nature and timeless character of both

- B.A. 1947, University of Redlands; M.A. 1950, Ph.D. I953, Harvard University. Associate Professor of Economics and Director of the Soviet-Bloc Foreign Economic Relations Project, University of Virginia. Author, Midde Eastern Economic Rezations with the Soviet Union, Eastern Europe, and Mainiand Chinh (1958), and Latin American Economic Relations with the Soviet Union and EAstern EUROPE (to be published 1959). Contributor to economic and area journals on international commercial policy and Soviet trade. 
state trading and economic warfare. Perhaps in these illustrations lies the explanation of why these two phenomena have never been accepted into economic analysis. State trading is the device of a faithless country whose announced goal is the conversion and subversion of the world. Economic warfare, in the German case, was a set of unusually despicable policies designed to subjugate less powerful neighbors.

But even if state trading and economic warfare were once the extraordinary and the bizarre, this certainly is no longer the case. State trading now embraces at least one-fourth of world trade, and the proportion is increasing. With one great bloc of nations dedicated to it and many other nations increasingly adopting forms of economic organization in which state trading is either desirable or necessary, it is apparent that state trading is a permanent part of the international economic scene. It not only has come of age, but it has also become respectable in the eyes of the world. Economic warfare is also a standard procedure employed by every major power. The few spectacular examples of economic warfare, however, such as the German case, have tended to obscure the day-to-day economic jockeying for power, which must be classed as economic warfare, too, since it transcends the use of trade merely for the benefits of the direct gains to be made therefrom.

The Meaning of State Trading

State trading is by no means crystal-clear in conception, and its ambiguity in operation is even more pronounced. The commonly used technical definition of state trading is trade which is conducted by a government or its agents. This may be elaborated upon to make provision for the government or its agents holding title to exports before transactions and acquiring title to imports. In order unmistakably to distinguish state from private trading, a dividing line may be drawn by specifying that state trading exists when the government, in addition to determining the kind and quantity of goods traded and their geographic distribution, also negotiates with respect to prices and the terms of the transaction.

At first encounter, it would appear that state trading exists only when the government acts both as a political unit and as the active economic decision-maker. This may, however, be too restrictive a definition. It can be argued that there are state controls over foreign trade which are so comprehensive that the transaction, nominally undertaken by private interests, has the same outcome as it would have had if the state itself had been the participant. Trade restrictions and discrimination, direct and indirect, bilateral balancing of trade, payments agreements, exchange controls, and other controls may well be so severe that while private parties may be the negotiators, they are, in fact, acting on behalf of the state. Thus, state trading is not wholly an objective phenomenon, definable in terms of the substantive provisions of the transactions or the organization of trade. Rather, state trading exists 
when national, in contradistinction to private, interests are primarily being pursued.

State and private trading share a spectrum with respect to intensity and coverage. At one end of the spectrum, there is no state trading. At the other end, there is nothing but state trading. The former case is rare; nearly every country trades to some extent, even if only for governmental consumption requirements. The United States, except for its surplus-disposal and stockpile policy, exemplifies this position. At the other extreme, however, the Soviet Union, East Europe, and Communist China have a complete monopsony of imports and monopoly of exports. In between are two other forms: a selective monopsony or near monopsony of particular imports, and a selective monopoly or near monopoly of particular exports. The bulk buying of agricultural products practiced by Great Britain and other European countries is an example of the former; state control of exports of primary products, as in Burma, is an example of the latter.

The form of state trading which a country adopts is a function of its national purposes and goals. There are at least four interrelated basic purposes: (I) protection of domestic industries, (2) improvement in the terms of trade, (3) assistance in the maintenance of control over the domestic economy, and (4) the conduct of economic warfare. It must be recognized, however, that state trading is not the only device by which these purposes may be accomplished. Indeed, other policies may be even more efficacious in some instances. Thus, a monopsony of imports may not be the most effective way to protect domestic industry against foreign competition; stringent exchange controls, quotas, bilateral trade agreements, and tariffs, among other policies, which exclude or raise the cost of competing imports, may, instead, be more advisable. Improvement in the terms of trade, likewise, may be accomplished equally well by either selective or comprehensive state trading or by a number of other policies. State trading is certainly one of the easiest methods, however, since it invests the state with substantially more bargaining power than any private trader could attain. As a buyer, the state trader can obtain imports at lower prices than would have to be paid by a competitive buyer; and as a seller, it can command higher prices than an individual seller on competitive markets can obtain.

When the domestic economy is completely controlled, however, state trading is not optional. In centrally planned economies, state trading is the necessary method for conducting trade, because anything other than state trading would expose the system to disruption through trade which was not designed to fit into the over-all program. A country operating under a centralized economic plan must have state trading to support that plan, to import in accordance with the preferences of the planners, and to export in accordance with the planners' view of the capabilities of the economy. Simultaneously, such a country may also use state trading to protect domestic industries and to attempt to improve the terms of its trade. 
Since state trading is national in character, it is only natural that it is a basic instrument of economic warfare. With control over a part or all of its trade, a nation may use this power to reward its friends, punish its enemies, to extract economic and political concessions, and to influence decisions not only of trading partners, but also of third countries. State trading, of course, is not the only weapon in the arsenal of economic warfare. Almost any kind of commercial policy can be used in this fashion if a nation so chooses. State trading, however, particularly in its most extreme form of state monopoly and monopsony, has unique advantages not shared by other techniques.

\section{The Meaning of Economic Warfare}

Before examining the special role of state trading in economic warfare, it is necessary to have clearly in mind just what economic warfare is. No satisfactory definition exists. Specific words have been used to try to denote its various special aspects. Economic aggression, penetration, infiltration, assault, drive, offensive, imperialism, attack, campaign, invasion, incursion, exploitation, and many others are currently in use. These terms all attempt to convey an emotionally adverse judgment both with respect to the act and the actor. The most general term-economic warfare-has been chosen here, with the realization that in so doing, the emotional, as well as the special-case, stigma still remains.

\section{A. Definition}

Economic warfare is defined as the conscious attempt to enhance the relative economic, military, and political position of a country through foreign economic relations. Several aspects of the definition require amplification. The action must be purposeful; otherwise, a nation merely in pursuit of the benefits of trade would be considered engaging in economic warfare if the action should improve its relative position. Economic warfare does not imply success. Rather, it is the attempt that counts; a nation may fail, and its action may have the reverse result.

Stress must be placed on the term "relative." It is the position of a country in the hierarchy of power, its position in relation to other countries, rather than an absolute accretion to power, which is relevant. It matters not whether this is accomplished by a country which gains more than other countries gain, or gains while other countries make no gain, or loses while other countries are losing more. Further, time and space are crucial elements in economic warfare. Thus, a country may, under certain circumstances, estimate that a short-run gain will more than offset a long-run loss. Likewise, a country may absorb a short-run loss in position if it anticipates that in the long run, the actions will improve its position. A country may also willingly take a loss in one area if the gain in another is sufficiently great.

Although economic warfare serves three principal purposes-economic, political, and military-it should not be thought that these are mutually exclusive. All may 
be pursued simultaneously, and all may be served, in varying degrees, by the same actions. The precise balance among them is determined by the total goals of the country. Many possible combinations exist: a country may absorb an economic loss if there is a political, military, or political-military gain, or if there is no change, save for sufficient net gain in one of the other elements. The purpose of undertaking economic warfare is seldom singular; rather, it is usually a complex decision involving, to some extent, all of these factors.

\section{B. Military Purposes}

The military aspect of economic warfare has two basic dimensions. One involves the use of economic warfare as an adjunct to military operations; the other involves its use with respect to the peacetime military establishment and the preparation for war. In both, however, the aim is substantially the same. In peace, in preparation for war, or in war, a nation wishes to acquire the maximum net resources.

In peacetime or in preparing for military operations, the use of force may well be inappropriate, since it may jeopardize future plans. Economic warfare, however, may accomplish the same purposes. Resources may be acquired by improving the terms of trade of the country with respect to the rest of the world or with respect to a single nation or group of nations. A country may, through trade, acquire such influence in another country that the latter will be willing to form a military alliance with the former rather than forego the trade, or at least be willing to be neutral in a possible conflict. Furthermore, the victim may be induced to join in economic warfare actions against still other countries. Economic relations, too, may assume such importance and be subject to such manipulation that the trading partner will lose some or all of its sovereignty. Many techniques can and have been bent to these ends, such as the use of trade to disrupt markets, switching trade to and fro in an unpredictable manner, manipulation of foreign exchange and gold holdings, and many others. So long as these actions are undertaken to acquire resources and deprive a potential enemy of resources, then economic warfare is operating in direct support of military operations.

In wartime, economic warfare is a natural and important adjunct to military operations. Again, the principal purposes are to prevent resources from falling into the hands of the enemy and to acquire as many resources as possible. These and like techniques will be used, although a military blockade may be neither feasible nor desirable.

A special case of economic warfare is the embargo or partial embargo in anticipation of possible war. A country may apprehend a distinct possibility of war between itself and another country and then decide that no trade should take place which might enhance the war-making potential of the prospective enemy. If and when war does come, the enemy will not be as well off as it would have been if there had been no embargo. This type of economic warfare has frequently been employed preceding military operations. It is easily recognizable as an action which confers 
short-run benefits on the perpetrator, but perhaps long-run benefits on the embargoed nation if the war does not come to pass. Most economies have such flexibility with modern technology that there is little for which a substitute cannot be found, even. if at a somewhat higher cost. When confronted with an embargo, a nation immediately begins to develop substitutes, using the resources formerly exported to bear most of the costs of the development. If the embargo period is an extended one, the country will have made the necessary substitution, so that the complete embargo of wartime does not impose any further burden. It is even possible that this kind of economic warfare will backfire and that the potential enemy will be forced prematurely, at a time when perhaps it can better afford it, to prepare itself for war by developing self-sufficiency. In this case, the most that the initiator has done has. been to impose on the enemy some added costs, but at the expense of facing not only a more adequately prepared enemy, but also one which is now insulated against this. particular kind of economic warfare.

\section{Economic Purposes}

It is easily discernible that the military purposes of economic warfare, although. directly in support of the military establishment, are basically economic in character. If a country is at war or proposes to go to war, then it must be said that economic warfare has a military goal; but if a country is not at war and does not necessarily intend to engage in warfare, then economic warfare may be serving an economic function. In both cases, the aim is the acquisition of additional resources and de-priving another country of resources. All of the measures usable in wartime are also usable in peacetime. Some of them, however, such as preclusive buying, because of their intimate association with active hostilities, may not be used.

Generally, the actions constituting economic warfare for economic purposes fall into five categories: (I) guaranteeing sources of supply, (2) guaranteeing markets, (3) improving the terms of trade, (4) denial, and (5) economic takeover. The first three of these do not necessarily import economic warfare; they may be normal commercial transactions undertaken in pursuit of profit. They may, however, also be undertaken for the specific purpose of increasing the economic power of a countrymore rapidly than that of other countries. A wide variety of techniques is availablefor attaining these ends, ranging from those which are also usable in wartime to. those apparently less predatory, such as gradually becoming a large trading partner and then threatening to withdraw trade, the building up of debts in other countries, the extension of credit, and many others.

Improvement in the terms of trade is accomplished by discrimination. The statetrader, as a buyer, will offer different prices in different markets, the higher prices. being offered where supply is relatively elastic. Purchases will be made to thepoint where the additional expenditures for additional units in different markets: will be the same, not to the point where prices are equalized in all markets. It is: the marginal expenditure in a given market, not the price, which guides the statetrader. The state-trader, as a seller, operates in a similar fashion, selling in different 
markets at different prices, the lower prices being asked in markets where the demand is elastic. The state trader sells to the point where the additional revenue in a given market is equal to the additional cost of the unit of exports sold in that market, not to the point where prices are equal in all markets.

\section{Political Purposes}

All of these acts of economic warfare may also be used to further the third important purpose of economic warfare-the pursuit of political advantage. This purpose, always important, has gradually assumed greater and greater importance as nations have become increasingly cautious about the use of force to achieve aims which transcend the economic benefits that may be conferred by economic warfare. The search for political power may take three forms. It may be quite general. A country may simply desire respectability and status. Many countries on the way up, in process of development or in the consolidation of revolutionary gains, may want, initially at least, only to be recognized and noted as a member of the family of nations. Other countries on the way back from a disastrous national experience may desire readmittance and a return to their former place.

The political purpose may also be manifested in a highly specific fashion. A country may wish to conclude an alliance or to obtain the vote of another in some international organization. Or it may want another country to eliminate a particular political or military leader, to undertake some change in domestic or foreign policy, or the like. The change sought may be either internal or external or both. In most cases, however, it concerns foreign policy, since it is in this field that the power position of the initiating country is most directly affected.

The ultimate degree of political as well as economic influence, however, is the takeover of another country. Just as economic warfare may be directed at reducing the flexibility of another country's economy to such an extent that the country can no longer make decisions with respect to its resources, so economic warfare may also be used to perform a political amalgamation, to deprive a country of its national sovereignty. In one sense, the takeover is the ultimate goal of all economic warfare, and the other objectives are but stepping stones to this end. This is true, however, only in a specific historic context, one in which a major world power feels itself endowed not only with the truth, but with the obligation to propagate it throughout the world. Throughout most of history, nations have been willing to set their sights much lower and have employed economic warfare to attain much more limited objectives.

\section{E. The Other Country}

Most of this article so far has been one-sided; it has taken the point of view of the nation which deliberately chooses to use economic warfare, and little has been said about the nations whose positions would deteriorate if this action were successful.

The victim may assume three basic postures. It may be passive and accept whatever solution the initiator of economic warfare proposes. This is a fairly rare 
phenomenon. Much more common is the situation in which the victim fights back, attempts to defend itself, and grudgingly, if at all, gives in. The victim may choose to fight on the grounds already chosen-to break the embargo, or to extricate itself from the burdensome balances or whatever other snare or snares the initiator may be using. It may also fight back by using a different policy to attempt to inflict harm, so that the pressure will be relaxed. Thus, a country holding large balances of a country using them to elevate its own position may employ quotas or other restrictive or discriminatory policies to raise the siege. The third posture is one in which both countries are engaging in economic warfare against one another, but with different purposes in mind. In this situation, a country with a political purpose in mind may successfully be engaging in economic warfare against another country which is successfully engaging in economic warfare for economic purposes against the first country. The political gains of the former, if achieved, may more than offset its economic losses; and the economic gains of the latter, if achieved, may more than offset its political losses.

\section{F. The Carrot and the Stick}

In the conduct of economic warfare, there are only two basic approaches. They are the carrot and the stick, cajolery and coercion. Each has its applications. They may be used individually, but not infrequently they are used simultaneously. Which is used and to what extent depends upon many variable factors.

Historically, it is clear that the stick has been used most frequently. After obtaining a position of economic influence in one country, another may threaten to stop making purchases, to cut off supplies, to refuse to pay its obligations, unless some concession-economic, political, or military-is made. The two most common sticks are the use of the large-trader position and that of the debtor. Whether or not these devices will work depends a great deal upon the economic position of the victim and the market for its products. If the market is relatively brisk, a victim may chance switching to other markets rather than make a concession. And depending on the size of the debt, a victim in a favorable internal economic and trade position may be able to withstand nonpayment for some time on the expectation that it will eventually be repaid, regardless of whether or not it gives in. On the other hand, a slow market for its products, depressed world conditions, a very large debt, a large percentage of trade in the hands of another country may leave a victim with no alternative but to pay premium prices for its supplies, sell at a lower price to the other country, and let its political or military policies be influenced by its trading partner. The stick, when thus wielded, however, damages the general prestige and standing of the country using it.

The carrot, on the other hand, is a prestige builder. It consists in the use of foreign economic relations to favor another country and thereby win its good will and support. Favoritism is a delicate instrument and does not carry with it the sometimes unpleasant connotations of coercion; it may, however, be just as effective. 
The usual method is to give more favorable terms of trade-either lower export prices or higher import prices-than would be provided in the world market, or to loan or give resources to the other country. On the basis of these economic favors, a country may expect in return reciprocal favors in the form of political support, an alliance, or perhaps neutrality. The recipient, however, may not be swayed by the economic benefits, in which case there is nothing the initiating country can do except return to the status quo ante, which still leaves the recipient in possession of some net gains.

One special aspect of the method of enticement may be labeled the drugged carrot. This method is most efficiently practiced by state-trading nations, since nations using private traders can seldom direct and shift trade readily. The recipient country becomes habituated to the favors of another and comes to regard these favors as fundamental to its welfare. So important do these economic considerations become that the recipient is deluded into thinking that concessions made to its benefactor are really in its own interest. The drugged carrot works best when there is at least an ostensible similarity of outlook and interest between the two countries. There is yet another aspect to the drugged carrot. While the recipient is being lulled by favors, the initiating country is gradually cornering a larger proportion of its trade, perhaps even a complete monopsony of some exports or monopoly of some imports. It is but a short step, then, from this vulnerable position to the use of the stick. In its stupor, the recipient may not recognize what is happening, and while it is still in this condition, the initiating country may withdraw, or threaten to withdraw the carrot.

A negative side to the use of the carrot must also be recognized. As a creditor nation, a country engaging in economic warfare makes itself vulnerable to the stick treatment from the recipient. If trade is large, this likewise makes the initiating country dependent on the recipient's markets and resources. This consideration, of course, makes little difference if one country is substantially economically more powerful than the other. The larger country can afford to pass up the debt repayment, can find other markets and new supplies. But the more comparable the countries are in economic power, or if special economic considerations render them proximate, the greater is the likelihood that this form of economic warfare may backfire and hurt the country which initiated it.

\section{G. Techniques of Economic Warfare}

All of those economic policies and acts which potentially can enhance the relative position of a country constitute the body of techniques of economic warfare. All of the particular acts may be classified as those which involve buying and selling and borrowing or lending.

The use of these techniques is consistent with either private or state trading. If private trading is the predominant form, however, then economic warfare can be waged only in so far as the government intervenes and acts, either positively or negatively, 
to influence the decisions of private traders. A government-imposed quota or increased tariff in a country where private interests do the foreign buying may be an act of economic warfare if its intent is to improve the country's relative power position. A loan, a sale or purchase of some product, bilateral balancing of trade, or many other measures may also constitute economic warfare. The ingredient common to all of these techniques, is government action. Private actions may be in the national interest, although not necessarily so intended; only government action is intended to be in the national interest.

The choice of the technique in any given instance will be determined by the goals being pursued, problems in applying the technique, and the estimated effectiveness of the technique, taking into account the possibility of countermeasures and a change in the underlying economic conditions.

\section{III}

\section{Unieue Role of State Trading in Economic Warfare}

Perhaps the most singular characteristic of state trading is that the nation which practices it is necessarily and automatically engaging in economic warfare. Comprehensive state trading stands alone in its power as an instrument that utilizes economic means to improve a country's relative economic, political, and military position. All external economic transactions in the hands of the government implies that trade no longer is solely a means for increasing the income of the country by taking advantage of lower-cost products in other countries. Economic decisions are transmuted into economic-political-military decisions, in which costs are balanced against benefits in all aspects of national life before transactions are concluded. This is so because when the state controls external economic relations, it must take into account the total interests of the state, not just its economic interests. Only a conscious effort would permit the pursuit of economic interests alone, and it is highly unlikely, even then, that a state-trading country could, in fact, limit itself to purely economic objectives.

A state-trading nation has attained bargaining power far beyond that which a private-trading nation possesses in its trade. Earlier it was shown how the state trader, acting as discriminating monopolist and monopsonist, can reap economic rewards greater than private traders can. Even in cases where state trading is not comprehensive, the economic benefits are richer, a result of sheer size in the market. In economic warfare, this greater influence is very important, because it can be translated into political and military influence. The willingness to forego the potentially greater economic benefits which can be extracted by the state trader may result in substantial political concessions. Alternatively, the economic benefits may provide the state trader with such a position of strength that it can force a favorable political or military policy on other countries. Even if a private trader acquired economic power comparable to that of a state trader, he would be in no position to 
translate this into other kinds of influence which might be beneficial to the state. $\mathrm{He}$ would be limited to economic objectives by the very nature of his role. State trading thus confers not only greater bargaining power, but also the ability to shift this power among the different goals of the state.

State trading is also a remarkably sensitive and flexible device for the conduct of economic warfare. All of the information and intelligence in the possession of the state can be made available to the state-trading organs immediately, and their conduct can be regulated in accordance with the interests of the state on a day-to-day basis. Government regulation of private trading, however, is much less attuned to immediate events and continual change. The measures, whether they be legislative or administrative, are more difficult to alter, once the course is set, and they frequently continue to implement their original objective beyond the time and under circumstances no longer beneficial to the state.

State trading is also relatively immune from interference by private economic interests. In a private-trading nation, even after government controls have set a course in the use of trade in economic warfare, there are always private interests seeking to undermine the government controls because their own interests are being harmed. Whether by circumvention or attempted circumvention of the controls or by agitation and pressure to alter the controls, interference can seriously weaken, render costly, or reduce the effectiveness of a measure. Once, however, a country has adopted state trading, the state is firmly in the saddle and can operate without fear of the nullification of its acts by domestic private interests.

Since economic warfare is not usually used alone, but rather in concert with diplomacy and with propaganda and psychological warfare, the relative ease and greater measure of coordination of state trading with the other policies of the government recommend it as a form of trading. Government controls over private trade are usually ad hoc and require new personnel and procedures. Accordingly, it is difficult to integrate private trading with diplomacy or with whatever propaganda and psychological means are being used.

It should not be thought, however, that state trading is a panacea and that economic warfare conducted by this method is necessarily the most desirable and most efficient. Aside from political and economic considerations which render any kind of economic warfare difficult, state trading possesses some disabilities not always shared by private trading, even under strict government controls. State-trading organizations are basically economic organizations, selling and buying and conducting business for the state. As economic units, their principal guide is price, economic gain, and economic loss. Despite the fact that the total interests of the state predominate, the state-trading organizations tend to think in economic terms, not in political or military terms. State-trading units and their political leadership must, therefore, be constantly alerted to the possibility that the state trader will act only for the economic benefit of the state and ignore broader aims. State trading, moreover, requires a bureaucracy and a relatively firm organizational structure. Thinking 
becomes hardened, and sudden change, often required in economic warfare, tends to disrupt and delay operations. Vested interests in a given course of action can negate a potential gain. And policy conflicts in political leadership and between the political leadership and the trading apparatus, too, can nullify some of the benefits of state trading.

\section{IV}

\section{State Trading and Economic Warfare in Action}

A. Conditions Conducive to Economic Warfare

Economic warfare has been relatively circumspect because the advantages of such activities have not been decisive. It requires a peculiar configuration of power relationships, economic and political conditions, and forces at work in the world before it can be successful. For instance, where power is approximately balanced among several nations, with most of the rest of the world having little to say, a course of economic warfare by one may be self-damaging, since all the others can, and probably will, counteract. Where one nation clearly dominates the world, there is likewise little scope for economic warfare. In prosperous times, when a victim may turn to others in case of need with reasonably hopeful expectations, economic warfare may also turn sour. On the other hand, in an unbalanced turbulent world, full of political change and economic instability, when a country or countries are making rapid strides toward development, when powers are rising and declining, when world economic conditions are unfavorable, there are greater opportunities for successful economic warfare.

The contemporary setting probably holds more promise for state trading and economic warfare than any period thus far. Power relationships are delicately balanced, and a large number of nations are plagued by economic and political instability. Many nations have aspirations which can be attained by economic warfare. Two gigantic power groups stand opposed, nearly equal in military capabilities. A third group, recent to independent status, seeks to remain aloof from the conflict, but also seeks to use both sides for its own ends. Each of the opposing sides seeks to extend its sphere of influence by whatever means are available-in particular, using economic means to curry favor and extend its influence in the third group, perhaps even to the point of dominating some of the weaker countries in that group. One of the groups practices state trading, which automatically means that its trade will be used to promote the political, economic, and military interests of the group. That same group has developed an intensely materialistic, yet missionary, philosophy which not only charges it with converting (or subverting) the world, but which also has an appeal for the weak, poor, directionless, and unstable elements in the third group. Some nations in the third group, feeling themselves victimized by the other groups, and for independent reasons as well, have adopted state trading not only to protect themselves, but also to enhance their own power position. Under these circumstances, it is only natural for state trading and economic warfare to 
wax strong. Indeed, the second half of the twentieth century, when its history is written, may well be known as the period of economic warfare.

\section{$\begin{array}{ll}\therefore & \text { B. The Contemporary Scene }\end{array}$}

The discussion so far has been abstract, dealing with general considerations. The reader no doubt has already illustrated with historical example many of the principles of state trading and economic warfare. Since space does not permit a full discussion of the examples, it may be desirable to confine examination to specific situations in recent years. It is proposed that the behavior of the Soviet Union in the postwar years be studied with reference to its state-trading activities and the role economic warfare has had in its foreign economic relations. This is appropriate, since the Soviet Union at the moment is the prime exponent of state trading in the world and in recent years at least has demonstrated considerable talent in using foreign trade to pursue its international aims.

In I957, Nikita Khrushchev, Chairman of the Council of Ministers of the Soviet Union, said, "We declare war upon you [the United States] in the peaceful field of trade." This is as candid and clear a statement of intent to wage economic warfare that the world has yet heard. It signifies that the Soviet Union plans to use trade to improve its position relative to the United States. However, this is a peculiar kind of economic warfare, in that it is being fought away from the home ground of either participant. Rather it is being waged with the trading partners of both countries. The Soviet Union is using economic means to improve its relative political and military position. Indeed, the Soviet Union seems not to have tried to benefit 'economically, and in some cases has taken marginal losses. Soviet objectives have not been in the United States, but rather in Asia, Africa, the Middle East, and Latin America. Economic warfare is only one facet of the total Soviet effort, which includes elaborate diplomatic maneuverings, propaganda and psychological warfare on a large scale, and extensive cultural exchanges.

On the economic front, two principal devices are in evidence. The Soviet Union, along with its East European bloc and Communist China, has systematically set about to increase trade with underdeveloped countries. The unique characteristic of the trade is that it is all conducted through bilateral trade and payment agreements which envision a bilateral balance of trade and no use of foreign exchange. The -second device is the establishment of lines of credit for raw materials, capital goods, arms, and technical assistance. Nearly every underdeveloped country has had Soviet and East European trade and credit offers, and many have accepted, resulting in a sharp percentage increase in this trade and credit extensions of about $\$ 2,400,000,000$, of which about $\$ 700,000,000$ ( $\$ 400,000,000$ in arms) has been utilized over the past four years.

“ Even so, relatively small amounts of resources have been involved, and the greatest Soviet efforts have been concentrated on just a few countries-Afghanistan, India, the United Arab Republic, and Yugoslavia: In order adequately to appreciate Soviet 
economic warfare, it is necessary to examine some specific examples and from them deduce the pattern of Soviet behavior.

\section{r. Finland}

Finland, although defeated in World War II, was not occupied, but did participate in Soviet reconstruction through heavy reparations. The Soviet Union required Finland to build a metals industry which, after reparations were paid, was not competitive. In order to avoid large losses and unemployment, Finland has maintained the industry by shipping three-fourths of its metals products to the Soviet Union, which also has purchased large quantities of other Finnish exports. Through triangular arrangements, the Soviet Union has encouraged Finnish trade with East Europe. The Soviet Union provides twenty per cent of Finnish imports and buys about the same amount of Finnish exports (about thirty per cent if East Europe is included). But even this strong position is enhanced by a Finnish export balance which the Finns have vainly tried to collect and by the fact that the Soviet Union and East Europe provide nearly all of the grain, oil, coal, and fertilizer requirements of the Finnish economy.

Soviet purposes in Finland are clear. At first, the Soviet Union wanted, and got, economic succor. More recently, the Soviet Union has wanted Finland in a position similar to the rest of East Europe-not necessarily Communist, but lacking enough freedom of action to steer a completely independent course. Finland has a military alliance with the Soviet Union, and its military establishment is deployed for use against Norway. Finland is required to support Soviet foreign policy in some respects, and any effort to discriminate against Finnish Communists is resented by the Soviet Union. So far, it has only been necessary to hint that Soviet import purchases will decline to force the Finnish Government into the desired action. In December 1958, the Finnish Government fell as a result of Soviet economic pressure which was applied when the Communists, the largest party in Finland, were left out of the new Government. Thus, Finland is an example of economic warfare in which trade has been used successfully to attain political and military ends.

\section{Yugoslavia}

At the other end of East Europe, Yugoslavia has been subjected to unremitting economic warfare. Its most interesting characteristic has been the wide variety of techniques used. The Soviet Union started out shortly after the war by assisting Yugoslavia, enlarging trade and providing some economic assistance. Tito, however, would not accept all aspects of Soviet policy. In order to force this acceptance, the Soviet Union, in I948, cut off trade, as did East Europe. Yugoslavia, however, was able to turn to the United States, Great Britain, and West Germany and did not yield to the Soviet Union. Continued pressure did not accomplish Soviet goals. After Stalin died, the new Soviet leadership adopted other tactics, and the period between r953, and $195^{8}$ was marked by intermittent improvement and deterioration in SovietYugoslav relations. In general, however, there was improvement. The Soviet Union 
and East Europe expanded their trade with Yugoslavia and committed themselves to loans of nearly $\$ 500,000,000$. Still, Tito refused to bow to Soviet ideological guidance. In May 1958, the crisis recurred. The Soviet Union, which had once before temporarily delayed loans, postponed two important loans, and trade began to dwindle. The West has once again come to the aid of Yugoslavia.

Thus, the Soviet Union started with the carrot, took to the stick in 1948, began using the carrot again in 1953, but with occasional lapses when the stick was brought out, and finally, in $195^{8}$ decided to use the full stick again. It is evident that Yugoslavia is incorrigible, and so long as some minimal assistance from the West is a realistic alternative, that country will continue to resist. The Yugoslav case illustrates that economic warfare does not necessarily imply success and requires for its effective operation the absence of a practical alternative which may be accepted without prejudicing the position of the victim.

\section{Iceland}

The Soviet Union and East Europe have accounted for from zero to one-third of Iceland's exports over the past five years. Trade volume has followed the fortunes of the local Communist movement and Communist participation in the Icelandic Government, as well as Iceland's squabbles with other Western countries, notably Great Britain. The Soviet Union has been most interested in trade when a Communist was in the Government, which happily coincided with a dispute with Great Britain resulting in a sharp decline in British imports from Iceland.

Iceland, plagued by serious inflation and facing economic crisis, and in continual dispute over fishing rights with West European countries, may have been nibbling on a drugged carrot. With one-third of its exports pledged to the Soviet Union and East Europe, Iceland is easily a candidate for the stick treatment. The Soviet Union has important interests in that country: a NATO air base and a large Communist Party. It is possible that Iceland will feel pressure for the elimination of the airbase and withdrawal from NATO in order not to displease its largest trading partner. With one-fifth of the vote going Communist, the Icelandic Government has felt itself compelled to include a Communist in its cabinet in recent years. Thus, the Soviet Union has used its trading position, made possible by state trading (private-trading countries continue to impose restrictions on Icelandic fish to protect domestic interests), to work itself into a position where important military and political objectives may be achieved.

\section{United Arab Republic}

Soviet economic warfare against the United Arab Republic is a drugged-carrot operation, using both trade and economic assistance. Starting with an arms loan in 1955, Soviet and East European activities have required, for payment, an increasing share of Egypt's cotton exports, to the point where the Alexandria market sells nowhere else and Egypt's Western markets have dwindled away. A Syrian arms deal followed. In 1957 , economic warfare, combined with diplomatic pressure, internal 
subversive activities, and propaganda; was leveled at Syria, with the apparent intent of a takeover in that country. This is one of the few times a nonviolent takeover had been attempted, and it failed. Rather than fall to the Soviet Union, Syria chose to join Egypt in the United Arab Republic.

The economic warfare continues. The arms debt is probably $\$ 400,000,000$; Egypt is supposed to get $\$ 175,000,000$ for economic development and $\$ 100,000,000$ for the Aswan High Dam. Syria is getting $\$ 160,000,000$ for economic development. To pay for the arms and as payments on the loans come due, trade must be redirected and Soviet influence will grow. Nasser has shown considerable independence so far. When thoroughly hooked, he is vulnerable to the stick, however. It should not necessarily be assumed, however, that Nasser has been completely lulled. In general, the Soviet Union has been following and espousing his policies in the Middle East-not the other way around. When the Soviet Union is deeply committed, Nasser may find difficulty, in fact or in fancy, in repaying loans unless the Soviet Union continues to support him politically. But in any event, both the United Arab Republic and the Soviet Union seem to be gaining, while the West is losing.

\section{Burma}

In Burma, Soviet economic warfare has so far been a failure. In I954, the Soviet Union's state-trading organ, with complete indifference. as to Soviet rice needs, began purchasing Burmese rice because that country had large stocks and was facing a crisis. Between r954 and I957, the Soviet Union, in concert with East Europe and Communist China, took, in barter deals, about fifteen per cent of Burma's exports. Two factors, however, deprived the Soviet Union of substantial political gains, perhaps even the drawing of Burma within its orbit. First, Soviet commercial policy was so inept that the Burmese Government was alienated through slow deliveries, high prices of Soviet goods, and many other irritants. Second, the rice market picked up in 1955, enabling Burma to sell rice for cash. Thus, Soviet political goals have been frustrated.

\section{Other Countries}

Since I953, nearly every underdeveloped country has been approached by the Soviet Union, with a proposition to expand trade or with a credit offer. Naturally, it has been the neutralist group which has received the greatest attention. But even Western-oriented countries, such as Pakistan, Turkey, Iran, Argentina, Brazil, and Uruguay, have expanded their economic contacts with the Soviet Union. Much of what has gone on could easily pass for normal commercial relations, but for the basic nature of trade in the Soviet Union. State-trading organizations have all too clearly attempted to keep political factors in mind in concluding transactions.

\section{Evaluation of Soviet Economic Warfare}

The fundamental world conditions must be kept in mind in attempting an evaluation of Soviet state trading and economic warfare. The basic political facts are that 
the old balance-of-power situation is gone and world power is precariously shared by three groups: the United States and its allies and friends; the Soviet Union and its sphere of influence; and a third group of new countries having varying degrees of allegiance to one or the other of the other groups and to a new kind of neutrality in which countries seek to advance their self-interest by noninvolvement with either group, but by exploitation of the rivalry between them to obtain political and economic succor from both. Intense political and economic nationalism characterizes the posture of the third group, which, recently freed from colonial status, seeks economic development and great increases in the standard of living by the most rapid route possible. Further, this third group is principally dependent on the export of primary products which are subject to wide price and quantity variations, a situation not compatible with smooth and steady economic progress. Soviet economic progress in the last forty years has been substantial, and many countries in the third group, in surveying the relative rates of growth of the world powers, seem to perceive in the Soviet example the model for their own growth, ignoring comparable growth of other powers when in the same stage of development as the Soviet Union.

Thus, world conditions have tended to promote the political and economic fortunes of the Soviet Union; and by cleverly fostering the idea that it is competing with the West, the Soviet Union has been able to dramatize this tendency. By remaining alert and sensitive to the economic problems of underdeveloped countries and by selectively using its political influence in causes popular among the third group of nations, the Soviet Union can make the basic structure of world conditions operate in its favor.

\section{The carrot with the stick held behind}

Appropriate to these world conditions and its own position in the world, the Soviet Union has chosen as its basic approach the carrot. This carrot has, in general, taken the form of mutually advantageous trade and the extension of credit. In themselves, these are powerful weapons, but the Soviet Union has tried to intensify their effect by orienting them to the special needs of primary-producing countries. In chronic need of foreign exchange, primary producers are offered trade through a device which obviates the need for foreign exchange-the bilateral trade agreement with bilateral balancing. Despite the fact that this technique is economically unsound-it distorts the most advantageous distribution of production and exchange of goods-it is highly welcomed because it assists in solving a difficult short-run problem. Sensitive to the economic development aspirations of underdeveloped countries, the Soviet Union offers capital goods in exchange for primary products-that is, it emphasizes the complementarity which is emerging between the Soviet Union and underdeveloped countries.

Soviet goals, however, are such that the carrot is not always the most efficient method. Thus, there have been instances where coercion has been attempted or used. This has been possible only in those situations and places where favorable economic 
relations had been built up, usually over a period of several years. It appears that the Soviet Union desires to be in a position where either the carrot or the stick can be used, depending upon its immediate goals and the situation. The carrot, therefore, has a strong narcotic in it. It is designed to maneuver the trading partner into heavy dependence on the Soviet Union for either a substantial proportion of its total supplies and its market, or particular supplies and market. The credit program increases this trade effect, makes the recipient dependent on the Soviet Union for parts and replacements, and leaves the recipient in a position where it must face the costs of unfinished projects should the Soviet Union withdraw its aid. The Soviet Union has even attempted, in part, to reap some of the benefits of a debtor position, such as that which worked so well for Germany before World War II. This is possible only in special circumstances, but it can succeed even when a recipient country occupies a debtor position on capital account. Delayed deliveries by the Soviet Union and prompt deliveries by the primary producer, a not uncommon circumstance, leave the Soviet Union in a debtor position on current account and can be used to subject the bilateral clearing account to economic pressure by the Soviet Union.

\section{Motives and goals}

The Soviet Union seeks political and military objectives in its economic warfare. They have two major foci. First, the Soviet Union seeks recognition as a world power, to be considered in all decisions in all parts of the world. Having labored so long under a cloud on the very fringes of the family of nations, the Soviet Union wishes to make up for lost time, now that its economic, political, and military capabilities are matters to be reckoned with on a global scale.

But the Soviet Union seeks not only recognition of its status. The particularized nature of Soviet economic warfare indicates highly specific objectives, nearly all of a political or military character. The Soviet Union wishes to break up the system of military alliances built up by the United States following World War II. Further, the Soviet Union wants to see potentially hostile military bases of the United States in foreign countries dismantled. Iceland is a case in point, as are Tunisia and Morocco, where the Soviet Union has incipient economic relations.

Political goals, however, are probably the most important. These range from diplomatic recognition by countries in Latin America, to the reinforcement of neutrality in India and Burma, and the encouragement of neutrality in Iran and Indonesia. Neutrality is, of course, not the end goal of the Soviet endeavors, but from the Soviet point of view, neutrality is to be preferred over a pronounced Western orientation. The Syrian experience indicates that the Soviet Union is prepared to go beyond the influence stage and, under propitious circumstances, will endeavor to control another state. The Soviet Union, appreciating fully that it is living in a tripolar world, seems content, for the time being, to assist the third group on its way up, especially 
since this is being done at some political cost to the West and a slight political benefit to the Soviet Union.

Economic motivation probably plays a quite subordinate role in Soviet economic warfare. The Soviet Union has not consciously sought economic gain beyond that which would derive from normal commercial activities in most cases. In the instances where there has been a substantial economic benefit to the Soviet Union involved, it is likely that it was unintended, a result of inexperience and overzealousness on the part of a Soviet trade organ. In another sense, however, economic considerations have been vitally important. It was only after thirty years of industrialization, unusually high investment, and deprivation of consumers that the Soviet Union was able to develop sufficient complementarity to consider undertaking the kind of economic warfare on which it is now embarked. Only during the past few years has the Soviet Union been able to consider mutually advantageous exchange of goods with primary producers. This provides them less with motivation, at least at this time, than with the capability.

\section{Conclusions}

State trading and economic warfare, once regarded as abnormal and deplorable departures from the classical world of comparative advantage, must now be accepted as permanent and irremovable fixtures in the world economic scene. They are also intimately related to one another, as a technique is related to an endeavor. State trading is unique in its relation to economic warfare, in that it is the only commercial policy by which the economic, political, and military interests of the state are automatically and simultaneously considered in making decisions about commercial transactions. It also possesses the advantage of providing a country with greater bargaining power, greater sensitivity to the state of affairs, and greater flexibility in meeting particular situations; and it brooks no interference by domestic interests.

Economic warfare, the self-conscious attempt to use foreign economic relations to elevate the interests of the state, is best exemplified by its goals, which are economic, political, and military benefits to the state, and by the approaches used by countries conducting economic warfare, which are the carrot-method of enticement and the stick-method of pressure and coercion. The acts of economic warfare are conditioned by world conditions, by the power alignments in the world, and by the role of the initiator of economic warfare in world affairs. Economic warfare has been successful historically, principally in coercing other nations to grant concessions, but success is not guaranteed. The stick cannot be counted upon if the victim has an alternative, and the carrot, most useful in general influence-building, is of little use in extracting concrete advantage. Frequently, the success or failure of economic warfare depends less upon the economic warfare itself and more upon accompanying diplomatic, cultural, propaganda, and psychological activity. Most important of all, the climate of world opinion and basic forces at work in any given period dictate the effectiveness of economic warfare. 
To the prevailing winds of nationalism, anticolonialism, desire for economic development, propensity for planning, and sense of urgency felt since the end of World War II among underdeveloped countries must be attributed some of the success of Soviet economic warfare in recent years. Soviet economic warfare itself has not displayed any great talent so far in getting things done, owing to inexperience, lack of resources, and an ideology which is not always helpful. The future will probably see an enlarged and better-conducted Soviet economic warfare, but not necessarily a more effective one, since in a tripolar world, success depends not only upon the Soviet Union, but also upon the West and upon the underdeveloped countries themselves, whose overriding concern is the avoidance of outside domination.

Whether it fails or succeeds in any given instance, economic warfare will persist. It will be employed by any power which has an expectation that it may thereby benefit. In particular, it is possible that the developing countries of Asia, Africa, and Latin America will use economic warfare, as the use of force, even on a local scale, increasingly falls into disrepute and desuetude. The major powers, to whom force is almost barred by its devastating and self-defeating consequences, will also increasingly turn to economic warfare, as well as other nonviolent means, to achieve their ends. 